\title{
Pro \& Cons for Discussion about the Implementation of the Election in the Pandemic Time Covid 19
}

\author{
Gede Ari Sastrawan ${ }^{1}$ \\ Universitas Pendidikan Ganesha, Indonesia ${ }^{1}$ \\ \{arisastrawan17122000@gmail.com\}
}

\begin{abstract}
The Pros and Cons of Implementing the General Election during the Covid 19 pandemic, this is currently happening among the community and is influenced by social issues whose impact is more likely to have negative effects. The implementation of PILKADA during the Pandemic Period has been regulated in PKUP RI No. 13 of 2020 is the implementation of the PILKADA regulations that have been made to regulate the implementation of the Pilkada, but these regulations do not necessarily guarantee the safety of the community in choosing candidate pairs and it is still a discussion of pros and cons among the community in a discussion, the author has the right to know and collect valid data through literature review through mass media information, and literacy, for the pros and cons of the implementation of PILKADA can provide answers that can convince the public in the implementation of Pilkada, then in general, when reviewed in a juridical study, the implementation of PILKADA is the duty and obligation of the state in state administration is to implement Constitutional Rights, implement laws and the existence of a period of moderation of office. The purpose of this research is to find out the pros and cons of the implementation of regional elections during the Covid 19 pandemic. The research method used is the empirical juridical research method, an approach which is based on the main legal material by examining the phenomena and legislation related to this research. Based on the research content, it can be summarized as follows: 1 . Implementation of regional elections and campaigns during the COVID-19 pandemic. 2. Implications of Law No. 4 of 1984 with Pkpu Ri No. 13 of 2020.
\end{abstract}

Keywords: Law No. 4 of 1984; PKPU RI No. 13 of 2020; Pros and Cons of Regional Election.

\section{Introduction}

The Indonesian state does not implement policies like other countries, but the Indonesian state applies policies through CIRCULAR LETTER NUMBER HK.02.01 / MENKES / 199/2020 CONCERNING COMMUNICATION TO HANDLING CORONAVIRUS DISEASE 2019 (COVID-19) apart from that stated in article 12 of the Constitution The President of the Republic of Indonesia then issued Presidential Decree (Keppres) of the Republic of Indonesia Number 11 of 2020 concerning the Determination of Health Emergencies, and several other appeals such as psychological distlancing, social distancing, adhering to health protocols (Diligently washing hands, wearing masks when leaving the comfort zone, and avoid crowding out), and obey government advice or policies in general. [Circular Letter Number HK 02.01 / MENKES / 199/2020 Concerning Communication for Handling Corona / Virus people who do not agree, but when quoting a 
statement from Ir Soekarno, that "My struggle is easier in facing the colonial era, while your struggle will be more difficult because it is against your own nation". From his statement there is a point, and in fact, during this pandemic, he did not only face the Covid 19 pandemic, but also faced criminal cases, for example, the Crime of Theft, the Crime of Murder, and various other criminal acts. There are several other cases such as cyeberlaw which are related to Hoax Information in the form of online and offline which until now in its legal urgency is still weak because there is a system that cannot be achieved and fulfilled.

The impact of covid 19, not only Indonesia is affected but the impact is global. The resulting impacts in facing this pandemic are quite alarming because this pandemic period does not only have an impact on health but also has an impact on the economy, agricultural industry, educational work, tourism etc. But behind the general impact there is also an absolute impact, namely the law itself, why law is said to be an absolute impact because law is the supreme commander, and is used as a basic reference in the state, therefore Indonesia is said to be a constitutional state by upholding justice[1].

In terms of the topic of discussion, during the Covid 19 pandemic, when examined in law, there were many deviations from policies and legal regulations regarding infectious disease outbreaks listed in article 14 paragraph (1) of Law No.4 of 1984. The contagious disease epidemic in question is the COVID-19 pandemic, but from these regulations there are many problems between the community and state officials regarding its implementation, besides that there are regional elections whose implementation is not balanced with other fields. The fields referred to are in terms of education, religious ceremonies, tourism and economic recovery. Why is PILKADA a problem? Because Pilkada has several core activities in it, one of which is campaign activities, and Pilkada activities. The issue that is currently still being discussed is whether the pilkada activity will lead to the growth of new clusters? The answer is, because pilkada activities can become clustered activities and lead to the growth of new clusters during this pandemic. Therefore, the author wants to know the extent to which "Implementation of Article 14 Paragraph (1) of Law No. 4 of 1984 on Contagious Disease Outbreaks, Implementation of Regional Elections during the Covid 19 Pandemic" which is currently still the pros and cons of its implementation besides justice during the pandemic. Covid 19, the truth is increasingly eroded, and a lack of understanding of the situation and enforcing the law itself[2].

\section{Method}

This research is a type of empirical law research, which identifies the application of norms or rules in society that are against the established rules so that there is a gap between das sein and das sollen. Empirical law can also be said to be a sociological study, which is meant by empirical legal research is legal research carried out by examining situations in the field or real events that have been experienced. The method used in this research is empirical legal research studies. Collecting data of this research using primary data with interview research and observation. Data will analysis using qualitative descriptive which the sources that Law No. 4 of 1984 in article 4 paragraph (1) concerning Outbreaks of Infectious Diseases in Criminal Provisions, and Administration / Implementation of Pilkada during the Covid 19 Pandemic, PKPU RI No. 13 of 2020 concerning Second Amendment to Regulations General Election Commission Number 6 of 2020 Concerning the Implementation of Elections for Governors and Deputy Governors, Regents and Deputy Regents, and / or Mayors and Deputy Mayors Simultaneously Continuing In Zero Disaster Conditions Corona Virus Diasease 2019 (COVID-19), and several regulations which contains the Regional Election and General Election during the Covid 19 Pandemic[3]. 


\section{Result and Discussion}

\section{Implementation of Regional Election and Campaign during the Covid Pandemic 19}

The Covid 19 pandemic is an Infectious Disease Outbreak as stipulated in Law No. 4 of 1984 and is also supported by the policy provided by the government through CIRCULAR NUMBER HK.02.01 / MENKES / 199/2020 CONCERNING COMMUNICATION TO HANDLING CORONAVIRUS DISEASE 2019 (COVID-19). This is a very detrimental impact on all fields such as Health, Education, industry, economy, work and social activities, especially the implementation of the Regional Head Election during this pandemic, therefore, it is necessary to confirm, carry out obligations and evaluate the implementation of Pilkada in the future. The creation of the Pilkada event is in dire need of human capital as a capable and capable driving force to fill the void of regional leadership. The principle contained in the Pilkada, basically emphasizes social justice without sharpening the slightest difference (including for individuals and groups)[4]. PILKADA from previous years are very important to be implemented because the benefits obtained in the implementation of this pilkada are, moderation of government agencies or regional head agencies, and their staff, but the things that impact the implementation of the pros and cons of the PILKADA are due to differences of opinion, suspicion, an element of hatred in the hearts of the people, and the imbalance in the application of the law in society, especially according to the point of view of society's own judgment. To make it easier and more specific, there are several core explanations for responding to the Pilkada implementation during the pandemic which is currently still being discussed in the community.

PILKADA is one of the second objects of election, Pilkada is basically the same as PEMILU which has an attachment in the implementation of democracy. Both were held to elect leaders directly. Pilkada is held to elect regional heads such as governors-deputy governors, regents-deputy regents and mayors-deputy mayors. Pilkada is carried out in a certain scope. This PILKADA during the Pandemic is a momentum that cannot be held, besides that this can also be a source of growth for new clusters in the confirmation of the Covid 19 pandemic, this is actually an obstacle to the constitution, and also an obstacle to its implementation[5]. To find out more about PILKADA, the legal basis has been regulated, one of which is, the General Election directly and simultaneously in Indonesia is divided into 3 types of elections, namely the General Election of President and Vice President; General Election of DPR, DPD, and DPRD; and Elections for Governors, Regents and Mayors. The legal basis is Law no. 7 of 2017 concerning General Elections and Law no. 1 of 2015 concerning Stipulation of PERPU No. 1 of 2014 concerning the Election of Governors, Regents and Mayors. Then it is operationally regulated in the General Election Commission Regulation (Kristiyanto, 2018)[6].

When reviewed in the General Guidelines for Facing the Covid Pandemic 19 for local governments, it is explained that regional elections are political activities to determine power, responsibility, obligations, and leaders in society, but if you look at the conditions that have occurred in Indonesia in the face of the COVID-19 pandemic, The Central Government through the General Election Commission Number 179 / PL.02-Kpt / 01 / KPU / III / 2020 has decided to postpone the election for governors and deputy governors, regents and deputy regents, and / or mayors and deputy mayors in 2020 in an effort to prevent the spread of COVID-19. This delay is one of the responses to the development of the current situation in the spread of the disease outbreak caused by the Corona Virus Disease 2019 (COVID-19) in the territory of the Unitary State of the Republic of Indonesia and by taking into account the official statement of the World Health Organization (WHO) which declares COVID-19 a 
global pandemic, The official statement of the President of the Republic of Indonesia stating the cause of COVID-19 as a National Disaster (Non-Natural Disaster) and the Decree of the Head of the National Disaster Management Agency (BNPB) regarding the Extension of the Status of Certain Disaster Disaster Disaster Outbreaks of Disease Due to the COVID-19 Virus in Indonesia.

Based on the conditions of the Covid 19 pandemic that the PILKADA activities were temporarily postponed due to the emergency conditions of Covid 19, in addition, several explanations were explained about the postponement of regional election activities carried out during the Covid 19 Pandemic which was revealed by several experts including:

a. The government must conduct an in-depth study of the articles in the existing election regulations, especially those related to emergencies. In general, the majority of these regulations allow elections to be postponed or rescheduled, or for polling stations to be moved. Some explicitly authorize election administrators to change election dates. Most do not, but EMBs tend to have broad authority over general emergencies that can include changing dates.

b. In areas where an absent voter must provide reasons according to a list of acceptable reasons. This list can be expanded both through the interpretation of existing provisions allowing for voting to be absent for health reasons (quarantine, etc.).

c. When the polling station is located in a care / quarantine facility, moving it to a location with fewer vulnerable people is a reasonable policy.

d. Election workers may be unwilling to serve voters because of health risks, which can make the election more difficult. Relocating to a more conducive polling station, where several electoral areas vote at the same location, or moving to a polling center, where each voter from a jurisdiction can vote at any polling place, usually a larger facility can reduce the total number of polling officers required, making it more efficient.

e. In many countries, persons with disabilities / persons with disabilities have the option of using roadside / vehicle voting; Voting workers carry their ballot cards or ballot signs into the car so that voters do not have to enter the building.

Some explanations of the conditions for implementing the PILKADA during the Pandemic are actually not easy to implement, because considering the impact of the Covid 19 pandemic, it is actually detrimental from various fields such as: Health, Economy, tourism, education, industry, trade and law. When talking about the law during the Covid 19 pandemic, refer to Law No. 4 of 1984 on Contagious Disease Outbreaks. Then the implementation of the PILKADA during the Covid 19 pandemic has had the latest legal basis, which has been regulated in Law No.1 of 2015 concerning Stipulation of Government Regulations in Lieu of Law No.1 of 2014 concerning Elections for Governors, Regents and Mayors. In fact, there are mechanisms that can be implemented if conditions compel or allow the regional head election stage to be postponed. The choice is in the form of a further election and a follow-up election. Article 120 of the Pilkada Law states that a follow-up election is a mechanism to postpone the election which later continues the halted stages, while the conditions for a further election are stipulated in article 120 paragraph (1) which reads: security, natural disasters, or other disturbances which resulted in the inability to carry out some stages of the Election, then a further election was conducted[7].

Apart from going through this mechanism, there are other alternatives, namely the selection of a follow-up in accordance with Article 121 paragraph (2) the mechanism is carried out for all stages in the sense that it starts from the beginning. Then technically, in 
anticipation of the spread of covid-19, the General Election Commission has issued a policy set out in KPU Decree Number 179 / PL.02-Kpt / 01 / KPU / III / 2020 concerning Postponement of Election Stages for Governors and Deputy Governors, Regents and Deputy Regent, and / or Mayor and Deputy Mayor of 2020. In general, there are 4 stages of holding the postponed regional head elections, including the inauguration of the voting committee, verification of the support requirements for individual candidates, the formation of the Voter Data Updating Committee, as well as updating and compiling the voter list.

There are several important reasons why the regional elections during the Covid 19 pandemic should continue to be carried out, here are the explanations:

\section{Implement the Law}

KPU member, I Dewa Kade Wiarsa Raka Sandi, said that the KPU had previously postponed the implementation of the pilkada stages in March. The postponement due to the corona virus pandemic (covid-19. However, after the delay, the government issued a Government Regulation in lieu of Pilkada Law Number 2 of 2020 as a legal basis for holding a democratic party at the regional level. "First, the KPU will certainly carry out the mandate of the applicable regulations," said Dewa. , in Jakarta, Sunday, June 22, 2020.

\section{No one can confirm when Covid-19 ends}

The next reason, said Dewa, is that no one can confirm when the Covid-19 pandemic will end. The government and the DPR then agreed that the simultaneous regional election will be held on December 9, 2020. The KPU also coordinates with the Covid-19 Handling Task Force. The task force's suggestion is that the pilkada can be continued as long as it is carried out according to health protocol safety standards. "Pilkada is continued in accordance with the joint decision of the government, DPR and election organizers. God.

\section{Constitutional rights}

The third reason, said Dewa, is regarding the constitutional rights to vote and be elected. Every five years, there must be a change of leadership. "When we decided to postpone the elections, we hoped that it could be continued after Covid-19 ended. However, over time, WHO conveyed its conclusions and views that this global pandemic will not possibly end in a short time. Covid- 19 will not disappear, "said KPU member Viryan Aziz.

\section{Budget governance}

Another reason concerns the election funds. If the elections are postponed past the year or in 2021, the budget that has been disbursed in 2020 will be wasted because it has passed the budget year. Meanwhile, what has been disbursed has reached Rp. 4.1 trillion. "This is what we have to think about (if we postpone it to the next year)," said Dewa.

Then before the formation of the PKPU Regulation during the Covid 19 pandemic at the implementation of the 2020 Regional Election, recently there was the implementation of KAMPANYE which was held in Purwokertho, Gorontalo, early September 2020 by a candidate pair of Regent and Deputy Regent by carrying out a Music Concert Activity that made the public not One of the controls in carrying out health protocol activities is not keeping distance or psychological distancing (Source https:/www.kompas.tv/live). Then after campaign activities carried out by several regions such as Gorontalo, solo, and others, the resulting impact was the growth of new clusters during the pandemic and an increase in positive confirmed cases of Covid 19, which is increasing. In the case that occurred, the Government and state officials had concerns about the implementation of the elections, 
especially in the implementation of the CAMPAIGN. To overcome feelings of concern and overcome cluster cluster growth which resulted in an increase in confirmed cases, the government together with the DPR and KPU to make a Perpu for the implementation of the 2020 Regional Election during the PANDEMIC Covid 19, the Perpu is PKPU RI No. 13 of 2020 concerning the Second Amendment to the Election Commission Regulation General Number 6 of 2020 concerning the Implementation of Elections for Governors and Deputy Governors, Regents and Deputy Regents, and / or Mayors and Deputy Mayors Simultaneously Continuing in Zero Disaster Conditions Corona Virus Diasease 2019 (COVID-19).

\section{Implication of Law No. 4 Of 1984 With PKPU RI No. 13 Of 2020}

Law No. 4 of 1984 on Communicable Disease Outbreaks is a law that has been specifically regulated regarding virus outbreaks which is the benchmark in facing the pandemic, the article of which is the focal point is article 14 paragraph (1) talks about the criminal provisions which state that Whoever deliberately obstructs the implementation of the epidemic control as regulated in this Law, shall be punished with imprisonment of up to 1 (one) year and / or a maximum fine of Rp. 1,000,000 (one million rupiah). When examined in Law No. 4 of 1984 on Communicable Disease Outbreaks, it tends to be more likely to offenders who still do not have confidence in disease, and especially in people who often cause problems, this has certainly become the main provision in the urgency of the legal umbrella in facing the covid pandemic period due to efforts to protect, affirm, and enforce an applicable law. When talking about the implementation of the elections. Whereas the legal basis is always copied and modified from several articles, one of which is PKPU RI No.13 of 2020 concerning the Second Amendment to the General Election Commission Regulation Number 6 of 2020 concerning the Implementation of Elections for Governors and Deputy Governors, Regents and Deputy Regents, and / or Mayors and Simultaneously Deputy Mayor Continues to Follow Up in Disaster Conditions Zero Corona Virus Diase 2019 (COVID19) [8].

Quoting the opinion of Beetham (2002) which states that the basic concept of democracy is political equality, with the principles of justice and equality that must be attached to each people individually, so that people are able to carry out their roles and functions in democracy (Apriani et al., 2020 The problem is, the epidemic caused by Covid19 has forced the government and society to rethink and prepare new schemes in implementing future democratic parties, in accordance with field dynamics, of course[4].Various kinds of analysis can be applied, to measure the extent of preparation and readiness of each element in the Pilkada later. The government is trying to take the best steps for policies regarding the implementation of PILKADA activities and CAMPAIGN activities to reduce the emergence of new clusters during the Covid 19 pandemic. As time goes by, if the PILKADA and KAMPANYE are carried out offline, there will be an increasing number of confirmed positive cases of Covid 19 due to the growth of new clusters, which started with the uncontrolled implementation of the campaign, the government, DPR, and KPU issued PKPU RI No.13 2020 concerning the Second Amendment to the General Election Commission Regulation Number 6 of 2020 concerning the Implementation of Elections for Governors and Deputy Governors, Regents and Deputy Regents, and / or Mayors and Deputy Mayors Simultaneously Continuing in Zero Disaster Conditions Corona Virus Diasease 2019 (COVID-19) in article 88 (Emphasizes more on Pilkada implementation regulations, which must comply with health protocols) and Article 89 (emphasizes more on the implementation of campaigns that are carried out virtually). This regulation is precisely to reaffirm the 
implementation of the PILKADA so that it is more upholding the health protocol, besides that this regulation is also formed, because it reflects on experiences from previous problems which tend to have an impact and arise a sense of concern[9].

In fact, logically, the Pilkada Activities during the Covid 19 pandemic had violated the Law of Law No. 4 of 1984, which was said to be a sloppy matter and had more theory than implementation. This is really a very big impact on mankind because during the Covid 19 pandemic, the stakes are that sick lives are a little called covid, while the lives that have been lost are said to be covid, so that this world seems to be filled with the words Covid 19. So , The government is trying to take the best steps for policies regarding the implementation of PILKADA and CAMPAIGN activities to reduce the emergence of new clusters during the Covid 19 pandemic. As time goes by, the implementation of PILKADA and KAMPANYE if carried out online will increase the number of confirmed positive cases covid 19 due to the growth of new clusters, which started with the uncontrolled implementation of the Campaign, the government, DPR, and KPU issued PKPU RI No.13 of 2020 concerning the Second Amendment to the General Election Commission Regulation No. 6/2020 concerning the Implementation of the Election for Governors and Deputy Governor, Regent and Deputy Regent, And / or Mayor and Deputy Mayor Simultaneously Continued in Zero Disaster Conditions for Corona Virus Diasease 2019 (COVID-19) in article 88 (More emphasis on Pilkada implementation regulations, whose implementation must comply with health protocols) and Article 89 (emphasize more on implementation Campaign conducted virtually). This regulation is precisely to reaffirm the implementation of the PILKADA to further re-enforce the health protocol, besides that this regulation is also formed, because it reflects on experiences from previous problems which tend to have an impact and arise a sense of concern[10].

In the discussion that the implementation of Law No. 4 of 1968 concerning Communicable Disease Outbreaks with the implementation of the Pilkada which has been regulated in PKPU RI No.13 of 2020 concerning the Second Amendment to the General Election Commission Regulation No. 6 of 2020 concerning the Implementation of Elections for Governors and Deputy Governors, Regents and Deputy The Regent, And / Or Mayor And Deputy Mayor Simultaneously Follow Up In the Zero Disaster Condition of Corona Virus Diasease 2019 (COVID-19) there is no longer a problem because :

a. The provisions of Law No. 4 of 1968 concerning infectious disease outbreaks discuss Article 14 paragraph (1) provisions delegated to people who often create problems and violate health protocol rules.

b. PKPU RI provisions No. 13 of 2020 concerning the Second Amendment to the General Election Commission Regulation No. 6 of 2020 concerning the Implementation of Elections for Governors and Deputy Governors, Regents and Deputy Regents, and / or Mayors and Deputy Mayors Simultaneously Continuing in Zero Corona Disaster Conditions Diasease Virus 2019 (COVID-19) which contains article 88 regarding the Rules for implementing the Regional Election during the Pandemic and Article 89 concerning the Rules for implementing CAMPAIGN in the pandemic period

c. The provisions of Law No. 4 of 1968 Article 14 Paragraph 1 can be linked to PKPU No. 13 of 2020 Articles 88 and 89, in terms of the rules of act of speech because they both contain regulations that are legality.

d. The provisions of the Law and PKPU are based primarily on article 12 of the Constitution of the Republic of Indonesia. The President then issues the Presidential Decree (Keppres) of the Republic of Indonesia Number 11 of 2020 concerning the 
Determination of Health Emergencies, and several other appeals such as psychological distlancing, social distancing, adhere to health protocols (Wash your hands frequently, wear a mask when you are out of your comfort zone, and avoid crowds), and obey general government policies or advice. CIRCULAR NUMBER HK.02.01 / MENKES / 199/2020 CONCERNING COMMUNICATION TO HANDLING CORONAVIRUS DISEASE 2019 (COVID-19) [Circular Letter Number HK 02.01 / MENKES / 199/2020 concerning Communication on Handling Corona / Virus Disease 2019 (Covid-19)

e. If the government is able to carry out a sharp analysis, then automatically the level of risk that is feared from the implementation of the Pilkada amid the threat of the Covid-19 outbreak will also decrease. Then, the existence of a legal decision in the form of Perppu No. 02/2020 concerning the implementation of the Pilkada on December 9 should actually be able to solve problems in the field. In the midst of the Covid-19 outbreak, the choice to seek the safety of the people as a priority is part of the government's fundamental task in administering the country as well as possible[4].

f. Utilizing the ICT (Information and Communication Technology) system in digitizing the general election system, then referred to as a digital election system that can be carried out online or offline. The system in question is the entire general election system starting from registration of candidate participants, updating voter data, proposing and determining candidate participants, campaigns, voting, re-voting, vote counting, recapitulation, and even supervision. Therefore DKPP and Bawaslu must also be able to adjust the KPU's development in the digital general election system[6].

g. Create a community with full confidence or trust so that people are confident and able to choose according to their agency, and there is also a need for an evaluation of implementation activities, to find common ground for problems that never end.

Then the thing that needs to be confirmed in the implementation of the Regional Head Election is the enforcement of health protocols, As we know, the Covid-19 health protocol requires us to be physical distancing and prohibits us from crowding, diligently washing our hands, applying awareness and ethics when coughing, sneezing or having a fever (Susiloet, al, 2020). In fact, the implementation of regional elections would have the potential to cause crowds. Thus, the KPU as the organizer should regulate several matters related to health protocols in the implementation of regional elections (Landman, \& Splendore, 2020), including: (1) Limiting the number of times during campaigns or other political activities related to regional elections; (2) Arranging patterns and mechanisms for verification and matching of voter data by officers (as has been implemented, from previously visiting each house to now being coordinated by the Head of RT) including data on support from individual candidates; (3) Limitation on the number of voters who are allowed to be in polling stations (TPS); (4) Providing hand sanitizer, body temperature measuring devices, and special booths for voters with signs of fever at each TPS; (5) Requiring body temperature measurement to every voter or officer who intends to enter TPS; (6) Requiring officers to carry out general health checks at certain designated health facilities to ensure their health and physical readiness prior to duty; (7) Requiring voters and officers to use personal protective equipment in the form of masks and several other devices; etc; (8) facilitate and guarantee the voting rights of citizens who are outside the voting area, with the option of sending ballots through the post office just like the elections for Indonesian citizens abroad[7]. 


\section{Conclusion}

In conclusion, during the Covid 19 Pandemic, of course it became a complicated problem in its resolution, besides that the resulting impact greatly affected the losses suffered by others so that the impact was not only in the health sector but also on education, industry, economy, work and social activities, but this can also be used as a momentum in the implementation of pilkada during the pandemic, this tends to lack of participation expected in the implementation of the elections because Pilkada implementation has been regulated in PKPU No. 4 of 2017 Article 5 paragraph (2) which confirms the implementation of regional elections and campaign implementation. Then whether PKPU No.4 of 2017 contradicts Article 14 paragraph 1 of Law No. 4 of Law of 1986 the answer is no, because this article has been covered by Circular Number HK 02.01 / MENKES / 199/2020 concerning Communication on Handling Corona / Virus Disease 2019 (Covid-19). Then the Government together with the DPR and the KPU made a Perpu to address concerns, and reduce the growth of new clusters which resulted in an increase in confirmed positive cases, this was done so that there was no freedom in the implementation of the Regional Head Election, and this was also so as not to become a commotion that made the public not sensitive to the implementation of regional elections that were carried out during the Covid 19 pandemic. Furthermore, to reaffirm that the PILKADA in this pandemic period is very important to be carried out for the period of periodization, the right to power, to fill the parliament, the leadership that has obligations and responsibilities, and strengthen ICT (Information and Communication Technology) in the implementation of the Regional Head Election during the Covid Pandemic 19.

\section{References}

[1] N. Fajriana, "Teleconference Dalam Pemeriksaan Perkara Pidana Di Pengadilan," Badamai Law J., vol. 3, no. 1, p. 60, 2018.

[2] K. Holtfreter, "Is occupational fraud 'typical' white-collar crime? A comparison of individual and organizational characteristics," J. Crim. Justice, vol. 33, no. 4, pp. $353-$ $365,2005$.

[3] Sugiyono, Metode Penelitian Kuantitatif, Kualitatif dan R\&D. Bandung: CV. Alfabeta, 2009.

[4] S. C. Rizki, “Assessing Differences In Opinion In Contestation Agenda In Contest In The Middle Of Covid 19 (In Bahasa)," J. Ilm. Muqoddimah, vol. 4, no. 2, 2020.

[5] S. Widihastuti, Citizenship Education for Elementary School / Mi Class VI. Jakarta: PT. Pustaka Insan Mandiri, 2008.

[6] F. Wisnaeni, "PANDEMIC IMPACT OF COVID-19: MODERNIZATION AND DIGITALIZATION OF THE GENERAL ELECTION COMMISSION OF THE REPUBLIC OF INDONESIA (KPU-RI)," J. Ilm. Galuh Justisi, vol. 8, no. 2, 2020.

[7] R. Kennedy, "Legal Discourse: Alternative Filling Patterns for Regional Heads during the Covid-19 Pandemic," J. Pembang. Huk. Indones., vol. 2, no. 2, 2020.

[8] BPKP, "Total Dana Penanganan Corona Rp. 800 T di 2020," CNN Indonesia, 2020.

[9] E. R. Quinney, "The Study of White Collar Crime: Toward A Reorientation in Theroy and Research,” J. Crim. L. Criminol. Police Sci, vol. 55, p. 208, 1964.

[10] N. Mishra, "Need of Article 370 in Present Political Setup in India: A Critical Study.," Int. J. Multidiscip. Res. Dev., pp. 232-236, 2015. 